\title{
Note on Caloplaca soralifera (Teloschistaceae, lichenized Ascomycetes) in Poland
}

\author{
Karina Wilk*, Lucyna Śliwa \\ W. Szafer Institute of Botany, Polish Academy of Sciences, Lubicz 46, 31-512 Kraków, Poland
}

\section{Abstract}

Caloplaca soralifera is reported for the first time from Poland. The species belongs to the group of sorediate representatives of Caloplaca lacking anthraquinones in the thallus. Detailed description of the species along with taxonomic comment is provided and its known distribution in the country is discussed and illustrated.

Keywords: lichenized fungi, Caloplaca, new record, distribution, taxonomy

\section{Introduction}

In accordance with the recent development of taxonomic studies on Caloplaca global and local knowledge of the genus increased rapidly [1-5]. Hundreds of species received modern circumscription and great number of new ones were described in the recent decade [6-8]. The ongoing revision of the Caloplaca genus in Poland indicated several species new to the country $[9,10]$. Further study resulted in discovery of $C$. soralifera Vondrák \& Hrouzek that is here reported for the first time from the area of Poland.

Caloplaca soralifera is most recently described species and belongs to the group of sorediate representatives of Caloplaca lacking anthraquinones in the thallus [11]. When fertile, the species is distinctive due to zeorine, orange colored apothecia. However, C. soralifera also occurs in a sterile form that is inconspicuous and probably often overlooked. Caloplaca soralifera was mainly reported from man-made substrata so far, e.g. concrete and mortar in rural/urbanized areas. The distribution range of this species is expanding [11].

The species is characterized in detail and a taxonomic discussion explaining the differences between most similar species is provided in the paper; its distribution and ecology is also discussed.

\footnotetext{
*Corresponding author. Email: k.wilk@botany.pl

This is an Open Access digital version of the article distributed under the terms of the Creative Commons Attribution 3.0 License (creativecommons.org/licenses/by/3.0/), which permits redistribution, commercial
} and non-commercial, provided that the article is properly cited.

\section{Material and methods}

The material was studied from the following herbaria: CBFS, H, KRAM, KRAP, KTC, MIN, POZ, PRM, UGDA.

Morphological characters were examined on dry material using a dissecting microscope. Anatomical characters were measured on hand-cut sections and squash preparations mounted in water. The structure of paraphyses and cortical tissues were observed in $25 \% \mathrm{KOH}(\mathrm{K})$. The granulation of tissues was observed in polarized light; pol+/pol- means that the granules reflect or do not reflect polarized light. The solubility of granules and/or crystals was tested with $\mathrm{K}$ and $65 \%$ nitric acid $(\mathrm{N}) . \mathrm{K}$ and $\mathrm{N}$ were also used for spot test reactions. The terminology for tissues follows $[2,12,13]$.

\section{Material used for comparison}

C. albolutescens (Nyl.) H. Olivier. United Kingdom. England, Tyneside, Northumberland, Stocksfield, 1878, W. Johnson (H-Nyl. 29845, holotype of Lecanora albolutescens Nyl.).

C. concreticola Vondrák \& Khodosovtsev. Ukraine. Khersonska oblast, Chaplinskiy district, ca. $4.5 \mathrm{~km}$ W of village Zaozerne, Kakhovskiy water channel, 2006.06.07, J. Vondrák \& J. Šoun (CBFS JV4636, holotype).

C. pratensis Wetmore. USA. North Dakota, Oliver Co., The Nature Conservancy's Cross Ranch Preserve, Sangor Ghost Town, 2007.06.05, M. K. Advaita 6100 (MIN, holotype).

C. xerica Poelt \& Vĕzda. Bulgaria. Eastern Rodopi Mts., Ljubimec, Malko Gradište, 2004.04.19, J. Vondrák 2181 (CBFS). Turkey: Eastern Turkey, Artvin, 2007.04.29, J. Vondrák 6443 (CBFS).

C. teicholyta (Ach.) J. Steiner. Poland. Pojezierze Kujawskie, Wrząca Wielka, 1983.10.19, Z. Tobolewski \& J. Sierakowska (POZ). Israel. Jordan Valley, Beth-Shean, 1996.06.22, J. J. Wójcicki \& M. Sugiera (KRAM-L 44784). 


\section{Results}

\section{Description of the species}

Caloplaca soralifera Vondrák \& Hrouzek, Graphis Scripta 18: 6 (2006).

HOLOTYPE: The Czech Republic, Central Bohemia, Rakovník Distr., Krrivoklát, Kalubice, by the small pond in the village, alt. $348 \mathrm{~m}, 50^{\circ} 02^{\prime} 56.3^{\prime \prime} \mathrm{N} 13^{\circ} 49^{\prime} 30.4^{\prime \prime} \mathrm{E}$, on horizontal side of concrete wall, 2004.12.28, J. Vondrák 3332 (PRM!).

Thallus epilithic, \pm thin, $150-250 \mu \mathrm{m}$ thick, areolate, irregular in shape, pale to dark grey, usually white pruinose; soralia present, marginal, soredia dark violet-grey, 20-50 $\mu \mathrm{m}$ diam. Areoles flat to strongly convex, scattered or crowded. Thallus cortex inconspicuous, almost completely obscured by hyaline crystals (pol+, insoluble in $\mathrm{K}$, soluble in $\mathrm{N}$ ), or seldom cortex well visible, up to $35 \mu \mathrm{m}$ wide, pale greyish, paraplectenchymatous, with necral layer ca. 5.0-8.5 $\mu \mathrm{m}$ wide; algae intermixed with distinct isodiametric fungal cells, without crystals.

Apothecia zeorine, crowded to more rarely scattered, sessile, round or angular and flexuous due to mutual compression, 0.3$0.8 \mathrm{~mm}$ diam.; disc flat, orange to dark orange; proper margin thick, persistent, raised above the disc, smooth, paler than disc; thalline margin thin, usually white pruinose. Parathecium well developed, 85-100(-110) $\mu \mathrm{m}$ thick, prosoplectenchymatous, lumina of cells elongated and narrow. Amphithecium present, with abundant algae, cortex indistinct, obscured by hyaline crystals (pol+, insoluble in $\mathrm{K}$, soluble in $\mathrm{N}$ ). Epihymenium granular, yellowish orange, $\mathrm{K}+$ red. Hymenium hyaline, 68$77(-110) \mu \mathrm{m}$ tall. Paraphyses simple to slightly branched, apical cells not thickened to slightly thickened, up to $5 \mu \mathrm{m}$ wide. Hypothecium hyaline, with irregular hyphae, sometimes with oil droplets. Asci 8-spored, spores polaribilocular, thin-walled, broadly ellipsoid, $12-15.3(-17) \times 5-8.5(-10) \mu \mathrm{m}$, isthmus $3.4-$ 5.4(-6.8) $\mu \mathrm{m}$ wide.

Pycnidia inconspicuous, immersed in thallus; conidia colorless, ellipsoid, 2.5-3.5 × ca. $1.5 \mu \mathrm{m}$.

Spot test reactions: thallus and soredia $\mathrm{K}+$ violet, $\mathrm{N}+$ violet; apothecial disc and proper margin $\mathrm{K}+$ red.

\section{Distribution and ecology}

The species was recorded on scattered sites both in the area of northern and southern Poland (Fig. 1). It is perhaps much more widespread in the country but undercollected.

Until now Caloplaca soralifera has been reported from the following European countries: Austria, Bulgaria, the Czech Republic, Germany, Slovakia, Romania [11], Britain [14] and Ukraine [15]. It has been also recorded from USA [4].

The species usually grows on artificial substrata (e.g., concrete, mortar, asphalt, nutrient-rich siliceous stones), and only rarely on natural ones (e.g., calcareous or base-rich siliceous rocks) [11]. In Poland the species was found on both considered substrate types - mainly on concrete and less frequently on calcareous stones.

EXSICCATES SEEN. Wetmore, Telosch. Exsicc. 89, 90, 91 (KRAM).

SPECIMENS EXAMINED. Poland. Pomerania Province, Wdzydze Landscape Park, Borsuk village, $53^{\circ} 56^{\prime} 60^{\prime \prime} \mathrm{N}$ $17^{\circ} 55^{\prime} 35^{\prime} \mathrm{E}, 2006.09 .13$, L. Śliwa 3638b with E. Adamska \& W. Gruszka (UGDA). Warmia-Masuria Province, Nizina Sępopolska lowland, Silginy, 1989.05.04, J. Nowak (KRAML 26309). Masurian Lakeland, Równina Mazurska plain, $1 \mathrm{~km} \mathrm{~W}$ of Rustkowo village, by road Nidzica-Wielbark,
1989.04.30, J. Nowak (KRAM-L 26198). Wyżyna Kielecka Upland, Przedgórze Iłżeckie, Klarnerowo, $2.5 \mathrm{~km} \mathrm{~N}$ of Starachowice, 1988.08, A. Lenard (KTC). Eastern Carpathians, Pogórze Przemyskie foothills, Rybotycze town, by Wiar river, 1993.09.07, J. Nowak (KRAM-L 34222), ibid., 1985.09.10, J. Kiszka (KRAM-L 31524). Western Carpathians: Kotlina Nowotarska, Czarny Dunajec town, 1999.08.08, B. Repa (KRAP), Gorce Mts, Góra Wdżar Mt. above Czorsztyn, 1993.06.17, J. Kiszka (KRAP).

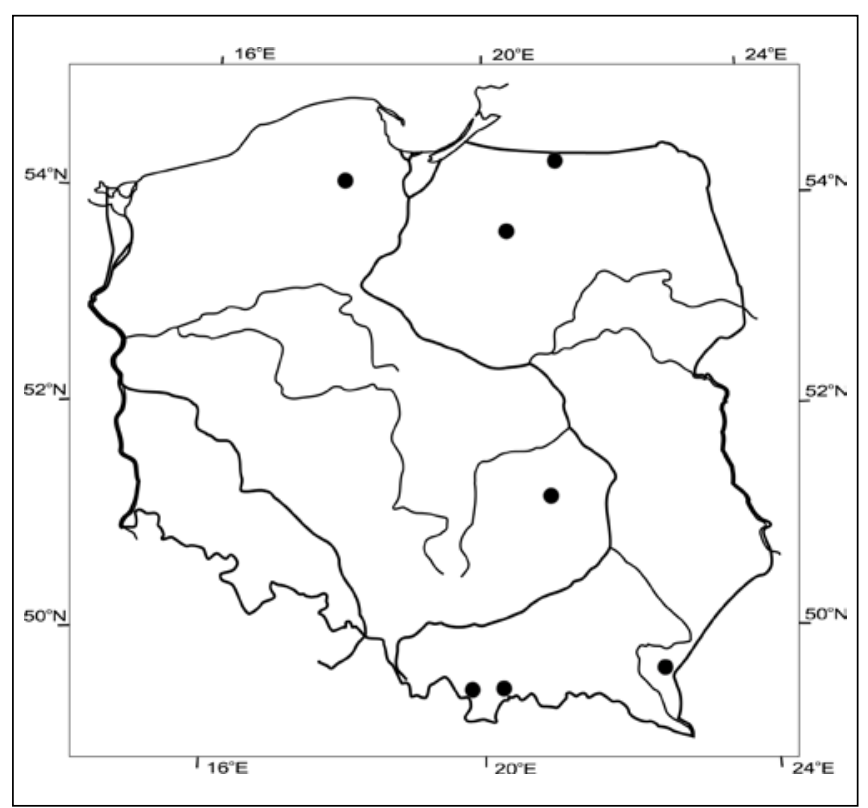

Fig. 1 Known distribution of C. soralifera Vondrák \& Hrouzek in Poland.

\section{Discussion}

Caloplaca soralifera is characterized by an areolate, grey, often whitish pruinose thallus. The apothecia are zeorine with proper and thalline margins present, orange and grey respectively. The dark violet-grey soredia produced on the margin of thalline areoles and presence of thalline cortex are most diagnostic characters for the species.

Caloplaca soralifera is closely related with C. xerica [11]. The latter species, however, differs in having esorediate, isidiate thallus and quite different ecology - it occurs mainly in xerothermic habitats and occupies base-rich siliceous rocks. Caloplaca chlorina (Flot.) H. Olivier is another similar taxon but it is distinguished by a typical lecanorine apothecia, rarely pruinose thallus and ecology; the species occurs mainly on siliceous stones and rocks (see also [11]). Concerning both habit of thallus and apothecia as well as ecology C. soralifera seems related to $C$. albolutescens. In case of the latter species lack of thalline cortex is a helpful, distinguishing character. Moreover, the whole thallus of C. albolutescens is filled by crystals on a cross section (pol+, insoluble in $\mathrm{K}$, soluble in $\mathrm{N}$ ) and the structure of the algal layer is almost invisible, whereas, in C. soralifera crystals obscure only the cortex and the structure of algal layer is clearly visible, with distinct isodiametric fungal cells intermixed with algae. What is more, the thallus of $C$. albolutescens is white and tartareous, instead of grey and compact in C. soralifera. When sterile, C. soralifera could be confused most likely with $C$. concreticola. Beside morphological similarities both taxa occur on the same man-made substrata 
such as concrete. The reaction with $\mathrm{K}$ of the thallus cortex is a main character distinguishing those species; C. soralifera reacts $\mathrm{K}+$ violet, whereas $C$. concreticola does not react with $\mathrm{K}$. When fertile, C. concreticola is easily distinguished from C. soralifera due to its brownish apothecia [16]. Finally, C. pratensis is somewhat similar to $C$. soralifera in the thallus appearance. The former species differs in soredia mainly present on the upper surface of the areoles and brownish apothecia. Caloplaca pratensis, however, is known only from North America so far [4].

The studied material from Poland was often misidentified as C. teicholyta. The latter species is in fact quite different than $C$. soralifera. It has thick thallus, roundish in outline, and lobate at its margin. The areoles in the center of thallus are dissolved into granules, isidia and soredia giving the surface scruffy-granular appearance. Moreover, C. teicholyta rarely forms apothecia; they are distinctly reddish when present.

\section{Acknowledgements}

The Curators of the following herbaria: CBFS, H, KRAP, KTC, MIN, POZ, PRM and UGDA are thanked for making the material accessible for study. The two anonymous reviewers are acknowledged for critical comments on the manuscript. This work was supported by the W. Szafer Institute of Botany of the Polish Academy of Sciences thorough the statutory fund and within the Program Supporting Research of Young Scientists.

\section{References}

1. Arup U. The Caloplaca holocarpa group in the Nordic countries, except Iceland. Lichenologist. 2009;41(2):111130. http://dx.doi.org/10.1017/S0024282909008135

2. Gaya E. Taxonomical revision on the Caloplaca saxicola group (Teloschistaceae, lichen-forming Ascomycota). Bibl Lichenol. 2009;101:1-191.

3. Søchting U, Lorentsen LB, Arup U. The lichen genus $\mathrm{Ca}$ loplaca (Ascomycota, Lecanoromycetes) on Svalbard. Notes and additions. Nova Hedw. 2008;87(1):69-96. http://dx.doi. org/10.1127/0029-5035/2008/0087-0069

4. Wetmore CM. New species of Caloplaca (Teloschistaceae) from North America. Bryologist. 2009;112(2):379-386. http://dx.doi.org/10.1639/0007-2745-112.2.379
5. Vondrák J, Ríha P, Arup U, Søchting U. The taxonomy of the Caloplaca citrina group (Teloschistaceae) in the Black Sea region; with contributions to the cryptic species concept in lichenology. Lichenologist. 2009;41(6):571-604. http://dx.doi.org/10.1017/S0024282909008317

6. Kondratyuk SY, Kärnefelt I, Elix JA, Thell A. New species of the genus Caloplaca in Australia. Bibl Lichenol. 2007;95:341-386.

7. Tretiach M, Pinna D, Grube M. Caloplaca erodens (sect. Pyrenodesmia), a new lichen species from Italy with an unusual thallus type. Mycol Prog. 2003;2(2):127-136. http:// dx.doi.org/10.1007/s11557-006-0050-7

8. Vondrák J, Šoun J, Hrouzek P, Ríha P, Kubásek J, Palice Z, et al. Caloplaca subalpina and C. thracopontica, two new saxicolous species from the Caloplaca cerina group (Teloschistales). Lichenologist. 2008;40(5):375-386. http:// dx.doi.org/10.1017/S0024282908007871

9. Wilk K. New or noteworthy records of Caloplaca (Teloschistaceae) from Poland. Mycotaxon. 2011;115(1):83-98. http://dx.doi.org/10.5248/115.83

10. Wilk K, Flakus A. Four species of Caloplaca (Teloschistaceae, lichenized Ascomycota) new to Poland. Mycotaxon. 2006;96:61-71.

11. Vondrák J, Hrouzek P. Caloplaca soralifera, a new species from Europe. Graphis Scripta. 2006;18(1):6-15.

12. Bungartz F. Morphology and anatomy of the fertile structures. In: Nash III TH, Ryan BD, Gries C, Bungartz F, editors. Lichen flora of the Greater Sonoran Desert Region. I. Lichens unlimited. Tempe AZ: Arizona State University; 2002. p. 24-35.

13. Ryan BD, Bungartz F, Nash III TH. Morphology and anatomy of the lichen thallus. In: Nash III TH, Ryan BD, Gries C, Bungartz F, editors. Lichen flora of the Greater Sonoran Desert Region. I. Lichens unlimited. Tempe AZ: Arizona State University; 2002. p. 8-23.

14. Hitch C. New, rare and interesting lichens. Brit Lich Soc Bull. 2006;99:34-46.

15. Khodosovtsev A, Vondrák J, Soun J. New lichenized and lichenicolous fungi for the Crimean peninsula (Ukraine). Chornomors'k Botan Z. 2007;3:109-118.

16. Vondrák J, Khodosovtsev A, Ríha P. Caloplaca concreticola (Teloschistaceae), a new species from anthropogenic substrata in Eastern Europe. Lichenologist. 2008;40(2):97-104. http://dx.doi.org/10.1017/S002428290800755X 